\title{
Haematological and blood chemistry changes in ewes and lambs following supplementation with vitamin $\mathrm{E}$ and selenium
}

\author{
BY G. M. J. HORTON* AND W. L. JENKINS \\ Faculty of Veterinary Science, University of Pretoria, \\ Onderstepoort, Republic of South Africa \\ AND ROSEMARIE RETTENMAIER \\ F. Hoffmann-La Roche \& Co., Basle, Switzerland
}

(Received 9 June 1977 - Accepted 23 January 1978)

\begin{abstract}
I. Four methods of vitamin $\mathrm{E}$ and selenium supplementation were evaluated using thirty-nine pregnant ewe-lambs fed on a ration containing $0.043 \mathrm{mg} \mathrm{Se} / \mathrm{kg}$ and $25 \mathrm{mg}$ vitamin E/kg. Treatments were control, fortified mineral mix (ESe salt) (300 $\mathrm{mg}$ vitamin E, $3 \mathrm{mg} \mathrm{Se}$ ), ruminal Se pellets ( $505 \mathrm{mg} \mathrm{Se}$ ), drench (300 mg vitamin $\mathrm{E}, 3 \mathrm{mg} \mathrm{Se}$ ) and intramuscular injection ( $600 \mathrm{mg}$ vitamin $\mathrm{E}, 3 \mathrm{mg} \mathrm{Se}$ ). Only ewes were supplemented, commencing approximately $50 \mathrm{~d}$ before parturition.

2. Birth weights were similar for all treatments and live-weight gains of lambs to $56 \mathrm{~d}$ of age were improved in all supplemented groups $(P<0.05)$. There were no clinical cases of nutritional muscular dystrophy.

3. Se concentrations in whole blood were more than doubled in both lambs and ewes drenched or injected; responses to ESe salt and pellets were much smaller.

4. Plasma tocopherol levels were increased in injected dams and their lambs $(P<0.001)$.

5. Haemoglobin concentration and erythrocyte counts were significantly higher $(P<0.01)$ in control ewes and lambs than in treated lambs.

6. Lactate dehydrogenase ( $E C$ I.I.I.27), creatine kinase $(E C$ 2.7.3.2) and aspartate aminotransferase $(E C$ 2.6.I.I) activities were increased in lambs from control, ESe salt and pellet groups $(P<0.001)$. Glutathione peroxidase ( $E C$ I I I. I.9) activity responded to Se supplementation in both ewes and their lambs $(P<0.001)$ and the response was highest in the injected group, followed, in order, by the drench, pellet, ESe salt and control groups.

7. These studies indicated that in terms of the haematological and blood chemistry changes investigated, the intramuscular injection was most effective, followed by the oral drench. Ruminal pellets and fortified salt were less satisfactory.
\end{abstract}

Selenium-responsive diseases have a wide geographic distribution and produce a variety of syndromes in sheep, including nutritional muscular dystrophy (NMD), infertility in ewes and unthriftiness in young animals. The occurrence of NMD in ruminants is most often related to low levels of Se in food (Oksanen, 1967), but may also be conditioned by the vitamin E status of the animals (Hidiroglou, Jenkins \& Corner, 1972).

It appears that both vitamin $\mathrm{E}$ and $\mathrm{Se}$ are anti-dystrophic agents acting synergistically, and several methods are in use for providing supplementary vitamin $\mathrm{E}$ and Se to ruminants. Prophylactic and treatment measures include the use of fortified salt (Paulson, Broderick, Baumann \& Pope, 1968), ruminal Se pellets (Andrews, Grant \& Brunswick, 1974), oral drenches (Andrews, Hogan \& Sheppard, 1976) and intramuscular injections (Burton, Keeler, Swingle \& Young, I962).

Although injections and drenching have the advantage of providing a known and desired amount of vitamin $\mathrm{E}$ and $\mathrm{Se}$, these methods are time-consuming and expensive. Se-fortified mineral mixes or blocks are a means of supplying a continuous intake of Se at a low labour cost, though individual intakes may vary considerably. Physiological amounts of Se may be released from intraruminal Se pellets for up to 3 years, though there is the risk of reduced

* Present Address: Department of Animal and Poultry Science, University of Saskatchewan, Saskatoon, Saskatchewan $\mathrm{S}_{7} \mathrm{~N}$ OWO, Canada. 
Table I. Composition of experimental rations fed to ewes before and after lambing

Daily intake (g/head)

Chemical analysis (/kg dry matter)

Crude protein (nitrogen $\times 6.25)(\mathrm{g})$

Crude fibre (g)

Calcium (g)

Phosphorus (g)

Selenium (mg)

Vitamin $\mathbf{E}$ (mg)
Lucerne

(Medicago sativa) Lucerne-maize

$\begin{array}{ccc}\text { hay } & \text { pellets } & \text { Mineral mix } \\ 2000 & 500(700) \dagger & 20\end{array}$

166
312
10.3
$2 \cdot 0$
0.039
26.8

130
173
8.7
4.6
0.061
17.6

0

150

54

0

o

* Mineral mixture was composed of sodium chloride, cobalt-iodized ( $350 \mathrm{mg} / \mathrm{g}$ ) and steamed bone meal $(650 \mathrm{mg} / \mathrm{g}$ ) and was fortified with vitamin A (1 $200 \mathrm{mg}$ retinol $/ \mathrm{kg}$ ) and vitamin D (Io mg cholecalciferol $/ \mathrm{kg}$ ). $\dagger$ Ewes were given $500 \mathrm{~g} / \mathrm{d}$ before lambing and $700 \mathrm{~g} / \mathrm{d}$ during lactation.

Table 2. Details of vitamin $E$ and selenium preparations given to ewes

$\begin{array}{cccc} & \text { Vitamin } \mathrm{E} & \mathrm{Se} & \\ \text { Treatments } & (\mathrm{mg}) & (\mathrm{mg}) & \text { Dose times }\end{array}$

Control
ESe salt*
Ruminal pellet
Drench
Intramuscular injection

0
300
0
300
600

* Mineral mix (Table I) fortified with vitamin E (1070 $\mathrm{mg} / \mathrm{kg}$ ) and Se (10.7 mg/kg).

$\dagger$ For $14 \mathrm{~d}$, starting at mid-gestation and at 0,28 and $56 \mathrm{~d}$ postparturition.

$\ddagger$ Mid-gestation.

$\$$ Mid-gestation, 0,28 and $56 \mathrm{~d}$ postparturition.

efficacy due to the formation of calcium phosphate deposits and the loss of pellets from the rumen (Andrews et al. 1974).

Blood enzyme determinations and tocopherol and Se assays are used in the diagnosis of vitamin $\mathrm{E}$ and Se deficiency diseases (Ammerman \& Miller, 1975). Glutathione peroxidase (EC I.II.I.9; GSH-Px) is a seleno-enzyme found in ovine blood and the activity of this enzyme may be the most sensitive measure of the Se status of animals (Godwin, Fuss \& Kuchel, 1975).

The object of this study was to evaluate the efficacy of four methods of vitamin $\mathrm{E}$ and Se supplementation using laboratory techniques and growth rate information.

\section{EXPERIMENTAL}

\section{Animals and rations}

Fifty-two Suffolk ewe-lambs (mean body-weight $58 \mathrm{~kg}$ ), which had been fed on a dystrophyproducing hay for 6 months, were assigned to the experiment after mating to a Suffolk ram, and allocated to five groups. There were twelve ewes in the control group and ten ewes in each of the four treatment groups. Of these, only the thirty-nine ewes found to be pregnant were used in this study (see Table 3). The sheep were held in open pens ( $10 \times 10 \mathrm{~m}$ ) provided with a roofed area $(4 \times 4 \mathrm{~m})$ and had access to fresh water. All animals were dosed with the anthelmintic thiabendazole (Thibenzole; Merck \& Co., Rahway, New York, USA) at the rate of $100 \mathrm{mg} / \mathrm{kg} \mathrm{I}$ and 3 weeks after breeding, to protect them from the effects of infection by internal parasites. 
Chopped lucerne (Medicago sativa) hay from the Vaal Hartz area, which is known to be deficient in Se, was fed at the rate of $2.0 \mathrm{~kg} /$ head per $\mathrm{d}$. Overt clinical signs of NMD were diagnosed in 3-month-old lambs maintained on lucerne hay from the same area in a concurrent trial (Horton, Owen, Horak \& Schröder, 1977). In addition, $0.5 \mathrm{~kg}$ lucerne-maize ( $\mathrm{I}: \mathrm{I}$ ) pellets/d were given during the last 4 weeks of the gestation period, after which the daily allowance was increased to $0.7 \mathrm{~kg} /$ head. A mineral mixture was available in feed boxes elevated to prevent consumption by the lambs. Sufficient mixture to allow an average daily intake of $20 \mathrm{~g} /$ animal was placed in the feed boxes every $14 \mathrm{~d}$. The composition of the lucerne hay, lucerne-maize pellets and mineral mixture is described in Table I. Ewes and lambs were weighed once each week on a standard time schedule and body-weight changes were calculated from the regression of body-weight $v$, time.

\section{Vitamin E-Se preparations}

Vitamin $\mathrm{E}$ and Se concentrations in the four treatment preparations as well as the times of administration are described in Table 2. All treatments commenced on the same day, approximately $50 \mathrm{~d}$ before parturition (i.e. at mid-gestation). Control ewes did not receive any supplementary vitamin $\mathrm{E}$ or Se during the experiment. The mineral mix given to one group (ESe salt) was fortified with vitamin E (Rovimix E Type $20 \mathrm{~W}$; F. Hoffmann-La Roche \& Co., Basle, Switzerland) and $\mathrm{Se}\left(\right.$ as $\mathrm{Na}_{2} \mathrm{SeO}_{4} \cdot \mathrm{IOH}_{2} \mathrm{O}$ ) (Table I) to provide the average intakes described in Table 2 over a period of $14 \mathrm{~d}$. Chromic oxide $(50 \mathrm{~g} / \mathrm{kg})$ was included in the ESe salt as a marker for the comparison of individual intakes. Faecal samples from all ten ewes were collected 6,34 and $62 \mathrm{~d}$ postparturition, $6 \mathrm{~d}$ after the provision of ESe salt.

Metal grinders of threaded mild steel and weighing Io g were used together with the ruminal pellets (Permasel Se pellets for sheep; Tasman Vaccine Laboratory (Australia) Pty Ltd, Dandenong, Australia). The action of a metal grinder on the Se pellet in the reticulum has been shown to prevent the formation of phosphate deposits on the surface of the remedial pellet and to increase the release of Se (Lee \& Kuchel, 1969). The weights of the Se pellets ranged from 9.6 $\mathrm{I}$ to $10.37 \mathrm{~g}$ (mean $\mathrm{IO} \cdot \mathrm{IO} \mathrm{g}$ ) and were stated to contain (mg/g): 50 elemental $\mathrm{Se}, 950$ iron powder. The drench consisted of an aqueous solution of vitamin $\mathrm{E}$ (Rovimix $\mathrm{E}$ Type $20 \mathrm{~W}$ ) and $\mathrm{Se}\left(\right.$ as $\mathrm{Na}_{2} \mathrm{SeO}_{3} \cdot{ }_{5} \mathrm{H}_{2} \mathrm{O}$ ). Intramuscular injections (Injacom E-SE; F. Hoffman-La Roche \& Co.) were administered bilaterally to the musculus semitendinosus and musculus semimembranosus. Injacom E-SE is stated to contain $100 \mathrm{mg}$ vitamin $\mathrm{E}$ and $0.5 \mathrm{mg} \mathrm{Se} / \mathrm{ml}$.

\section{Analytical methods}

Proximate components in the foodstuffs were analysed by standard procedures (Association of Official Agricultural Chemists, 1970). Venous blood samples were withdrawn from the jugular vein using vacuum tubes (Venoject; Comopharm, Elkton, Maryland, USA). Samples were taken from ewes at lambing and then 28,56 and $84 \mathrm{~d}$ postparturition. Blood samples were taken from lambs at birth and at 28 and $56 \mathrm{~d}$ of age. Se was determined by the method of Olson, Palmer \& Cary (1975) and vitamin E as described by Hashim \& Schuttringer (1966).

Haemoglobin $(\mathrm{Hb})$ concentration was determined using a haemoglobinometer (Coulter Electronics, Hialeah, Florida, USA). Erythrocyte count, mean corpuscular volume (MCV) and total leucocyte count were measured using a Coulter Counter (Model FN; Coulter Electronics). GSH-Px activity was determined by the method of Günzler, Kremers \& Flohe (I974), aspartate aminotransferase ( $E C$ 2.6. I I ; AAT) as described by Karmen (I955), creatine kinase ( $E C 2$.7.3.2; CPK) by the method of Weismann, Colombo, Adam \& 
Table 3. The number of experimental animals in each of the treatment groups and the average daily weight gains $(A D G)$ of lambs from birth to $56 d$ of age

\begin{tabular}{|c|c|c|c|c|c|c|}
\hline & & & eatment & & & \\
\hline & Control & ESe salt & $\begin{array}{l}\text { Pellet } \\
\text { (Se) }\end{array}$ & $\begin{array}{l}\text { Drench } \\
(\mathrm{Se}+\mathrm{E})\end{array}$ & $\begin{array}{c}\text { Injection } \\
(\mathrm{Se}+\mathrm{E})\end{array}$ & SEM \\
\hline No. of ewes & 7 & 6 & 8 & 9 & 9 & \\
\hline No. of lambs & & & & & & \\
\hline Single & 7 & 5 & 5 & 6 & 7 & \\
\hline Twins & 0 & 2 & 6 & 6 & 2 & \\
\hline Triplets & 0 & 0 & 0 & 0 & 3 & \\
\hline Total & 7 & 7 & I I & 12 & 12 & \\
\hline Mean birth-weight (kg) & $4 \cdot 5$ & $4 \cdot 7$ & $4 \cdot 8$ & 4.5 & $4 \cdot 5$ & 0.15 \\
\hline ADG of lambs (g) & & & & & & \\
\hline Total & 240 & $310^{*}$ & 262 & 289 & $317^{*}$ & $19 \cdot 2$ \\
\hline Single lambs only & 240 & $323^{*}$ & 302 & 332 * & $327^{*}$ & $20 \cdot 1$ \\
\hline
\end{tabular}

Richterich (1966) and lactate dehydrogenase (EC I . I I . 27; LDH) was assayed according to the procedure of Wroblewski \& LaDue (I955).

Only results for the lambs and ewes with lambs are presented. The numbers of animals in each group are given in Table 3. Analysis of variance and mean comparisons by Scheffè's test were carried out according to methods described by Snedecor \& Cochran (1967).

\section{RESULTS AND DISCUSSION}

Analysis of the feedstuffs revealed that the lucerne and lucerne-maize pellets fed to the ewes contained 0.039 and $0.06 \mathrm{Img} \mathrm{Se} / \mathrm{kg}$, and 26.8 and $17.6 \mathrm{mg}$ vitamin $\mathrm{E} / \mathrm{kg}$ respectively (Table I). A ration of $2 \mathrm{~kg}$ lucerne and $0.5 \mathrm{~kg}$ lucerne-maize pellets, therefore, would contain $0.043 \mathrm{mg} \mathrm{Se} / \mathrm{kg}$ and $25 \mathrm{mg}$ vitamin E/ $\mathrm{kg}$. The Se concentration in the ration was less than the minimum dietary level of $0.1 \mathrm{mg} / \mathrm{kg}$ necessary for the prevention of NMD according to Allaway \& Hodgson (1964) but higher than the critical level of $0.025 \mathrm{mg} / \mathrm{kg}$ given by Lindberg \& Lannek (1970). This marginal level of Se probably explains the significant growth response in lambs from supplemented ewes in the absence of overt signs of NMD in the non-supplemented group.

Mean birth-weights were similar for all treatments and averaged $4.7 \mathrm{~kg}$ (Table 3). Average daily gains to $56 \mathrm{~d}$ of age were significantly lower for control lambs than for treated lambs $(P<0.05)$. Differences between the daily gains of treated groups were reduced considerably when only single lambs were considered, and for supplemented groups single lamb gains were on average approximately $34 \%$ higher than those for control lambs.

Oldfield, Schubert \& Muth (1963) reported that NMD did not occur in lambs from ewes whose blood contained more than $0.06 \mu \mathrm{g} \mathrm{Se} / \mathrm{g}$. Mean Se concentrations were above this level even in the control group (Table 4) which is consistent with the absence of clinical cases of NMD during the trial. Se concentrations in whole blood from lambs resembled those in ewes (Table 4), and with the exception of ESe salt, these values followed similar trends during the postparturition sampling period (Fig. I). These results therefore indicate that a good maternal transfer of Se occurred in the drench and injection groups.

Blood Se concentrations in both lambs and ewes from the ESe-salt group were only approximately $17 \%$ higher than control values, which is not consistent with the two- to 
Table 4. Mean tocopherol and selenium levels in jugular vein blood from ewes and their lambs after parenteral and oral administration of vitamin $E$ and $S e$

(Mean values calculated from samples taken from ewes at lambing and then 28,56 and $84 \mathrm{~d}$ postparturition, and from lambs at birth and at 28 and $56 \mathrm{~d}$ of age; for details of nos. of animals in each group, see Table 3)

Treatment $\dagger^{\dagger}$

\begin{tabular}{ccccccc}
\cline { 2 - 5 } & Control & ESe salt & $\begin{array}{c}\text { Pellet } \\
(\mathrm{Se})\end{array}$ & $\begin{array}{c}\text { Drench } \\
(\mathrm{Se}+\mathrm{E})\end{array}$ & $\begin{array}{c}\text { Injection } \\
(\mathrm{Se}+\mathrm{E})\end{array}$ & SEM \\
$\begin{array}{c}\text { Ewes } \\
\mathrm{Se} \\
(\mu \mathrm{g} / \mathrm{g} \text { whole } \\
\text { blood) }\end{array}$ & 0.080 & $0.095^{*}$ & $0.095^{*}$ & $0.198^{* * *}$ & $0.239^{* * *}$ & 0.005 \\
$\begin{array}{c}\text { Tocopherol } \\
(\mathrm{mg} / \mathrm{l} \text { plasma) }\end{array}$ & 0.29 & 0.38 & 0.28 & $0.49^{*}$ & $1.21^{* * *}$ & 0.07 \\
$\begin{array}{c}\text { Lambs } \\
\begin{array}{c}\text { Se }(\mu \mathrm{g} / \mathrm{g} \text { whole } \\
\text { blood) }\end{array}\end{array}$ & 0.079 & 0.090 & 0.082 & $0.176^{* * *}$ & $0.207^{* * *}$ & 0.006 \\
$\begin{array}{c}\text { Tocopherol } \\
\text { (mg/l plasma) }\end{array}$ & 0.44 & 0.60 & 0.42 & 0.49 & $1.31^{* * *}$ & 0.09
\end{tabular}

Values significantly different from control group: $* P<0.05,{ }^{* * *} P<0.001$.

$\dagger$ For details of treatments, see p. 195 and Table 2.
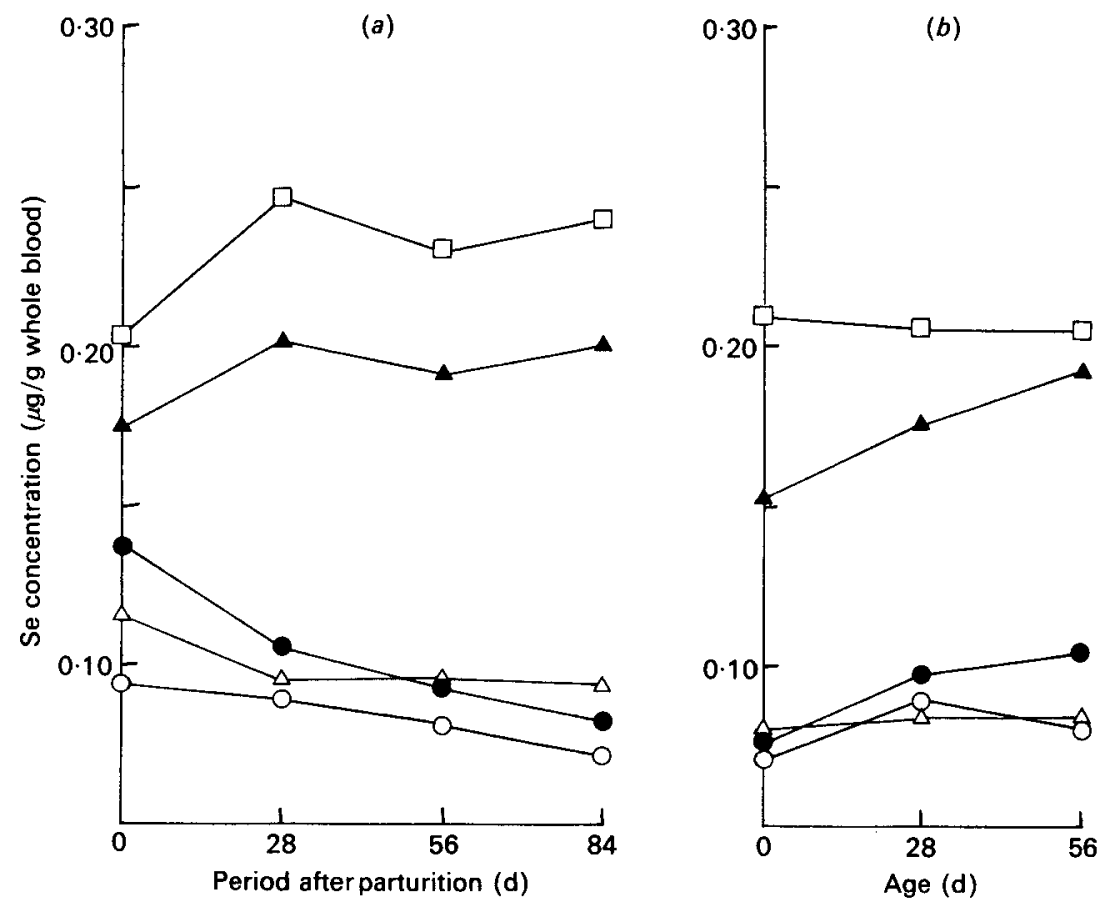

Fig. I. Selenium concentrations in whole blood from $(a)$ ewes and $(b)$ lambs after the ewes were given supplementary vitamin $\mathrm{E}$ and $\mathrm{Se}$ as follows: control (O), ESe salt mix (๑), ruminal Se pellet $(\triangle), \mathrm{Se}+$ vitamin $\mathrm{E}$ drench $(\Delta)$, and intramuscular injection (Se + vitamin $\mathrm{E})(\square)$; for details of treatments, see p. 195 and Table 2. 

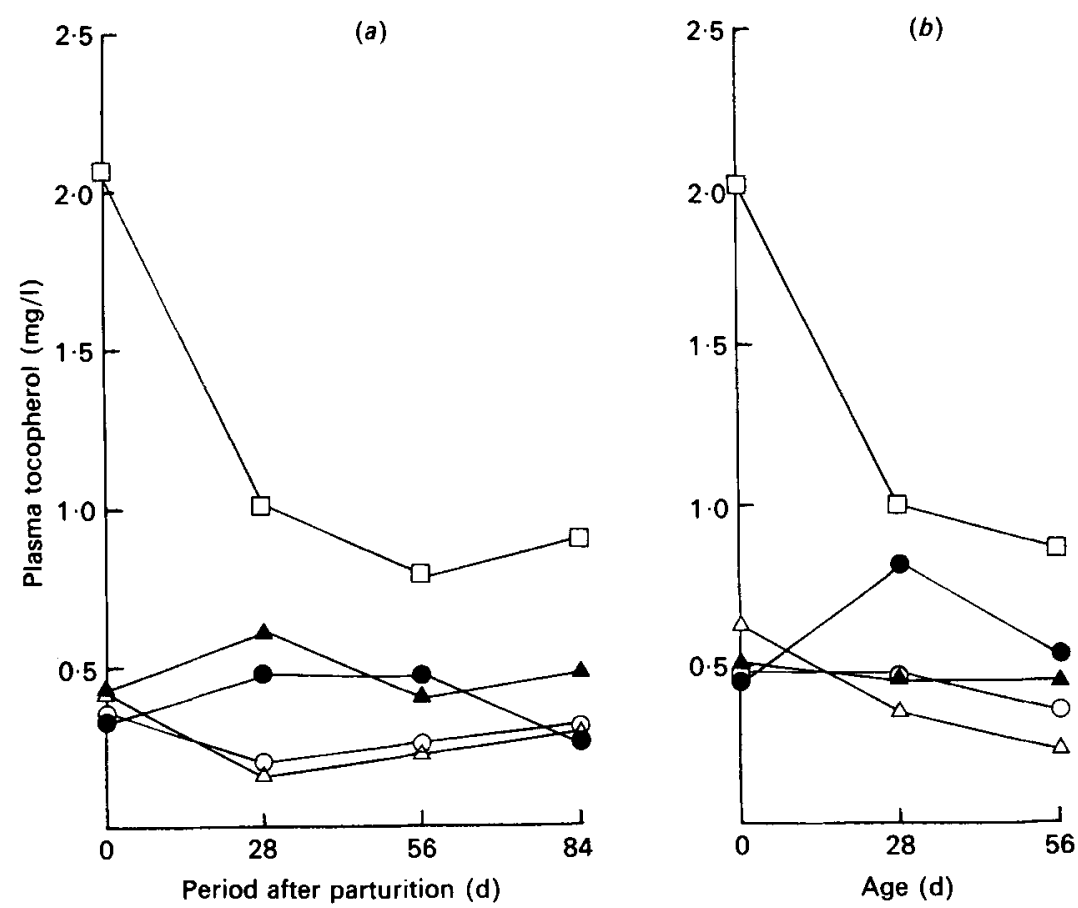

Fig. 2. Plasma tocopherol concentrations in $(a)$ ewes and (b) lambs after the ewes were given supplementary vitamin $\mathrm{E}$ and $\mathrm{Se}$ as follows: control $(O)$, ESe salt mix (O), ruminal Se pellet $(\triangle)$, Se+ vitamin $E$ drench $(\Delta)$, and intramuscular injection (Se + vitamin $E)(\square)$; for details of treatments, see p. 195 and Table 2.

threefold increases reported by Paulson et al. (I968) using similar fortified mineral mixes. The wide variation in ESe-salt intake, as evidenced by the faecal $\mathrm{Cr}_{2} \mathrm{O}_{3}$ concentrations (range $0.02-0.6 \mathrm{I} \mathrm{g} / \mathrm{kg}$ ) may have been a contributing factor.

Marginal improvements in blood Se concentrations (approximately $12 \%$ ) for the group receiving the heavy Se pellets were likewise disappointing, and by no means comparable to earlier reports by Andrews et al. (1974) using almost identical pellets. This discrepancy, however, may have been due to differences in both the type of animal used, and the nature of the diet. Growing and mature sheep, grazing non-legume pastures in the previous study, contrast with the lactating ewes and their lambs fed on a lucerne-based diet in the present work. It is therefore quite possible that high food intakes by lactating ewes may have been associated with a higher rate of pellet rejection, and that $\mathrm{Ca}_{3}\left(\mathrm{PO}_{4}\right)_{2}$ coatings may have formed more readily on the Se pellets in the present investigation.

Blood Se concentrations in both ewes and lambs were doubled after drenching and trebled after intramuscular injections. On the premise that blood Se concentrations represent the level of available dietary Se (Perry, Beeson, Smith \& Mohler, 1976), these results indicate that although drenching was highly effective, there was a greater loss of Se when administered orally rather than parenterally. Lower retentions of Se given orally may have been due to transformation of Se to unavailable forms in the gastrointestinal tract (Cousins \& Cairney, 196I).

Although vitamin E supplementation increased plasma tocopherol concentrations in both dams and their lambs with the exception of drench lambs (Table 4), amounts in all but the injected group were below the critical level of approximately $0.81 \mathrm{mg} / \mathrm{l}$ blood required to prevent the occurrence of NMD in lambs (Culik, Bacigalupo, Thorp, Luecke \& Nelson, 
Table 5. Mean haematological values for ewes and their lambs after parenteral and oral administration of vitamin $E$ and $S e$

(Mean values calculated from samples taken from ewes at lambing and then 28,56 and $84 \mathrm{~d}$ postparturition, and from lambs at birth and at 28 and $56 \mathrm{~d}$ of age; for details of nos. of animals in each group, see Table 3)

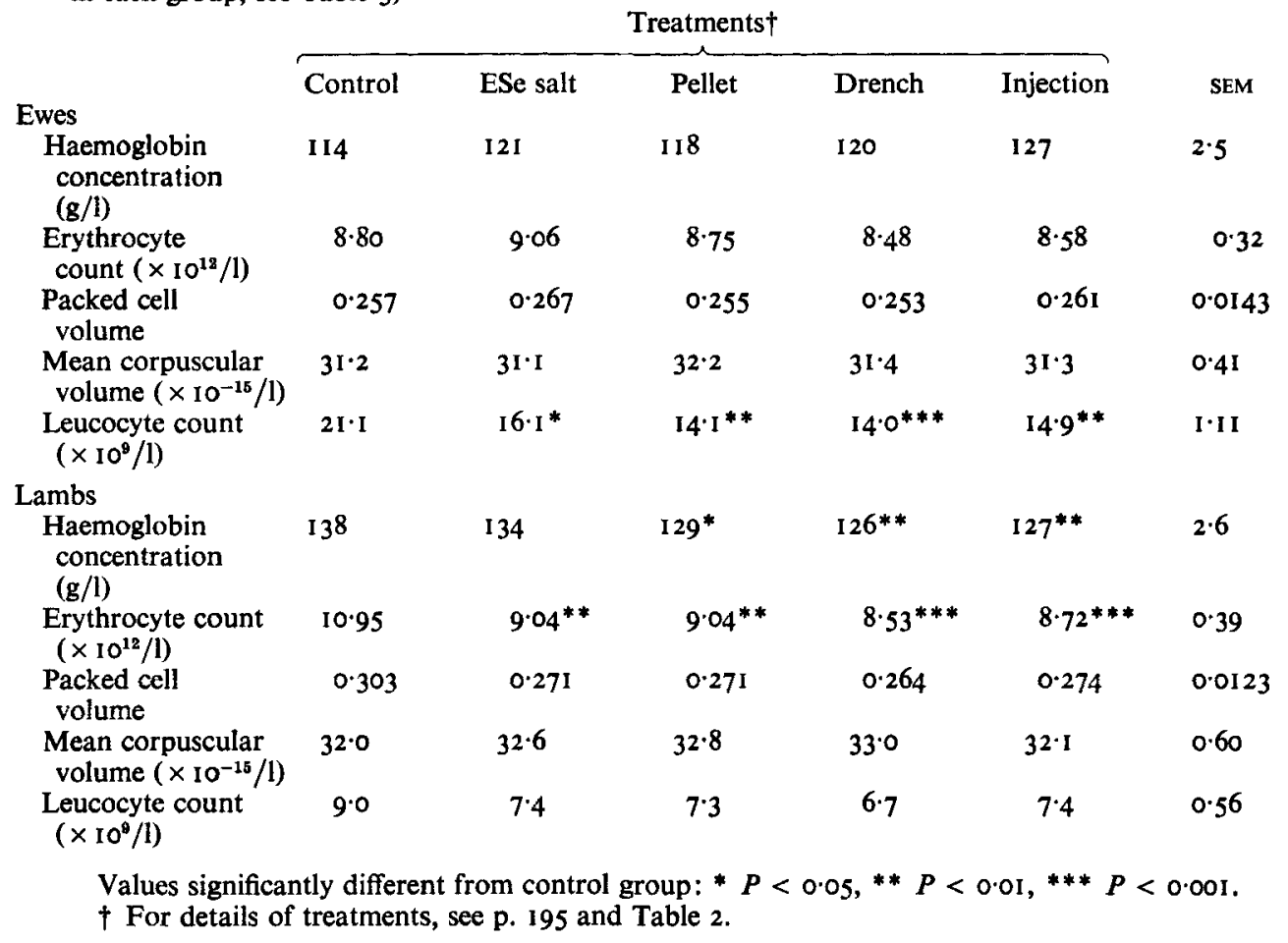

I95I). The amount of vitamin $\mathrm{E}$ injected $(600 \mathrm{mg})$, however, was twice that in the ESe salt or drench. These results do not support the concept of a maternal barrier to the transfer of vitamin E suggested by Paulson et al. (1968). Increased tocopherol levels have also been reported in lambs from ewes with vitamin E implants (Hidiroglou et al. 1972) which suggests that the route of administration may be important, since Alderson, Mitchell, Little, Warner \& Tucker (197I) have shown that vitamin E degradation occurs in the rumen.

Tocopherol levels in both injected ewes and their lambs on day o were approximately twice as high as values $56 \mathrm{~d}$ later (Fig. 2). Hidiroglou et al. (1972) found no improvement in tocopherol concentrations of lambs at birth after implantation of tocopherol pellets in the parent ewes at mid-pregnancy, though levels did increase fourfold I4 and $28 \mathrm{~d}$ later, only to decrease thereafter.

Normal values for $\mathrm{Hb}$ concentration, erythrocyte count, packed cell volume and $\mathrm{MCV}$ (Table 5) indicated that there was no interference in erythropoiesis or normal erythrocyte destruction in any of the ewes. Increased $\mathrm{Hb}$ concentrations $(P<0.01)$, erythrocyte counts $(P<0.001)$ and packed cell volume in control lambs are similar to those reported by Buchanan-Smith, Nelson, Osburn, Wells \& Tillman (1969) with lambs fed on a low-Se diet, and could be due to an abnormal haemopoeisis in the bone-marrow and a shortened erythrocyte life-span (Tucker, 1974). Leucocyte counts for control ewes were approximately $50 \%$ higher than for treated ewes. Values for lambs followed a similar trend. The mild lencocytosis is indicative of tissue necrosis on the low-Se ration, though it is surprising that 

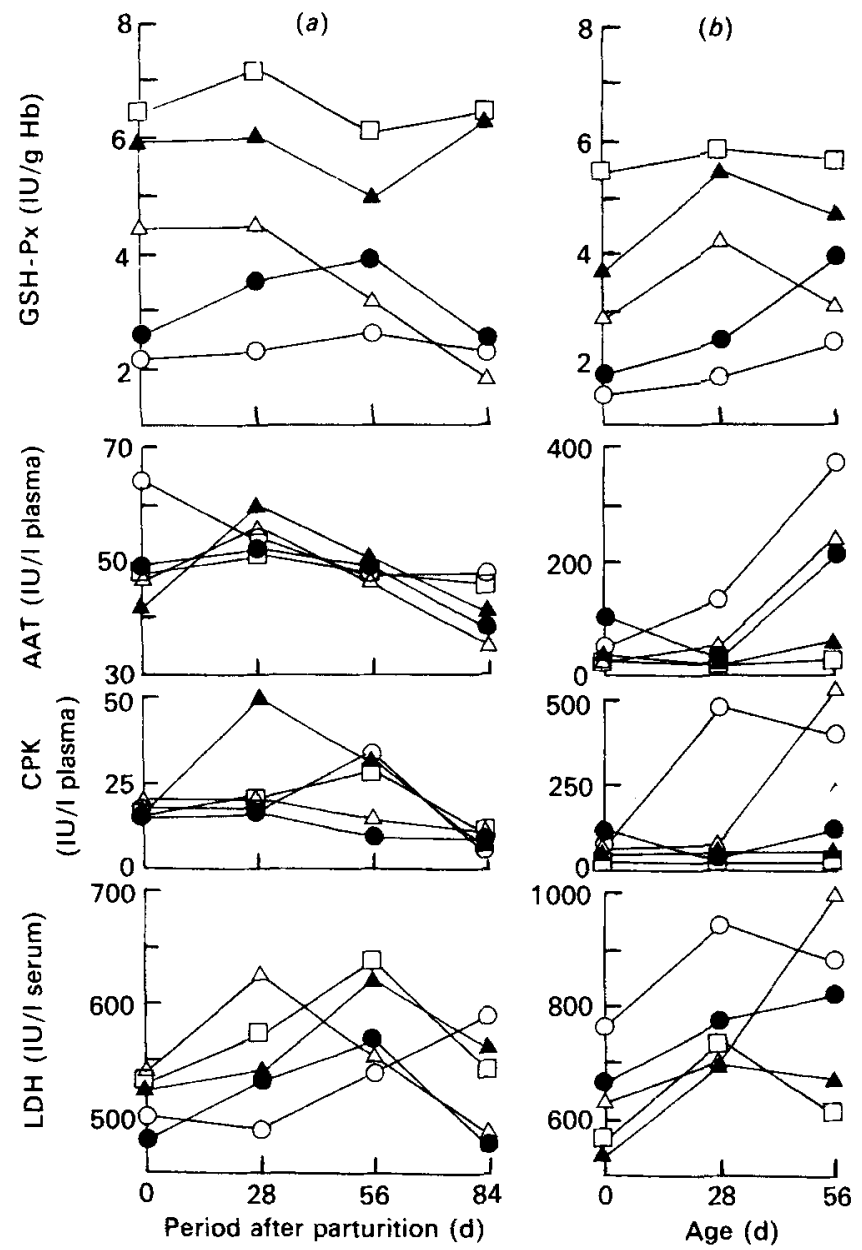

Fig. 3. Effects of vitamin $E$ and selenium supplementation on the activities of glutathione peroxidase (EC I.II.1.9; GSH-Px), aspartate aminotransferase (EC 2.6.I.1; AAT), creatine kinase (EC 2.7.3.2; CPK) and lactate dehydrogenase (EC 1.1.1 .27; LDH) in $(a)$ ewes and $(b)$ lambs. Ewes given the supplement as follows: control $(O)$, ESe salt mix $(\bullet)$, ruminal Se pellet $(\triangle)$, Se + vitamin $\mathrm{E}$ drench $(\triangle)$ and intramuscular injection (Se + vitamin $E$ ) ( $\square$ ); for details of treatments, see p. 195 and Table 2. Hb, haemoglobin. One unit of activity is defined as the amount catalysing the transformation of $1 \mu \mathrm{mol}$ substrate $/ \mathrm{min}$ at $25^{\circ}$ (International Union of Biochemistry, I965).

the differences reached significance $(P<0.00 \mathrm{I})$ in the instance of the ewes rather than the lambs.

Although LDH values of ewes did not follow a definite pattern (Fig. 3), mean values were significantly $(P<0.0 \mathrm{I})$ lower in lambs from ewes that received either the drench or the injection (Table 6). Similar findings have been reported for ewes (Tollersrud \& Ribe, 1967) and for lambs with experimental MMD (Paulson et al. 1968; Tollersrud \& Ribe, 1967).

Similar CPK activities were observed in plasma from ewes in the five treatment groups. CPK levels in control lambs increased tenfold by day 28 compared with those from drenched or injected ewes which remained at normal levels throughout the $56 \mathrm{~d}$ preweaning period. Increased CPK activity has also been reported by Boyd, Leyland \& Baker (1975) in dystrophic lambs.

AAT activity followed a similar pattern to CPK, which is not surprising since they are 


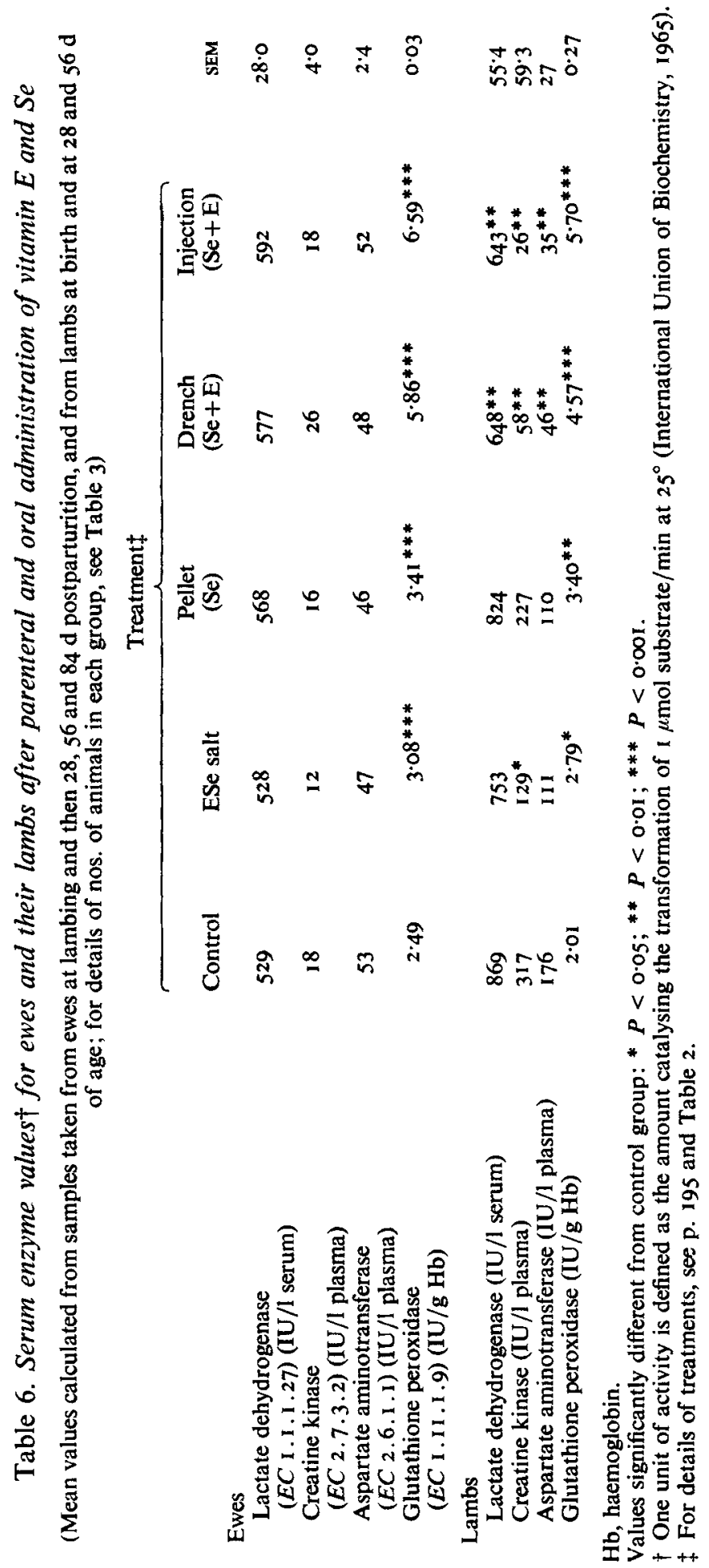


both indicative of cell destruction. Small increases $(P<0.05)$ in AAT activity in ewes shortly after lambing were also reported by Tollersrud \& Ribe (1967), and are of doubtful significance. Plasma AAT values remained at approximately $40 \mathrm{IU} / 1$ plasma in lambs from injected and drenched ewes throughout the study, but increased significantly $(P<0.01)$ in the other groups, reaching values of almost $400 \mathrm{IU} / 1$ plasma in control lambs (Fig. 3). Hopkins, Pope, Baumann \& Kowalczyk (1966) found that whereas Se only alleviated the dystrophy temporarily, vitamin $\mathrm{E}$ was required for a complete cure, and that AAT activity increased in lambs supplemented with Se alone. While low enzyme activities in lambs from ewes receiving either the drench or the injection (vitamin $\mathrm{E}$ plus Se), and increased levels in lambs from control ewes and ewes with ruminal pellets (Se only) support these findings, values for lambs given ESe salt do not. The ESe salt mix was fortified with both Se and vitamin $\mathrm{E}$, and this was reflected in increased tocopherol levels in the plasma from lambs. However, mean Se levels in the blood from these lambs (mean $0.090 \mu \mathrm{g} / \mathrm{g}$ ) were significantly lower $(P<0.001)$ than those in either the drench (mean $0.176 \mu \mathrm{g} / \mathrm{g}$ ) or injected group (mean $0.207 \mu \mathrm{g} / \mathrm{g}$ ). This evidence therefore suggests that vitamin $\mathrm{E}$ supplementation alone may not be sufficient, and that adequate levels of $\mathrm{Se}$ in the blood are also required for normal plasma AAT activity.

GSH-Px activity was increased in both ewes and lambs after Se supplementation and was highly related to blood Se levels $(r 0.64)$. The relative activities were ranked the same for both ewes and lambs and followed almost identical patterns during the first $56 \mathrm{~d}$ period (Fig. 3). Respective GSH-Px activities were 2.3 and 2.8 times higher for drench and injection groups than for control animals. Responses following the other two treatments were smaller with GSH-Px activities approximately I. 4 times higher than control values. Ammerman \& Miller (1975) have stated that since GSH-Px activity is a function of available Se, the activity of this enzyme may be a more reliable indicator of Se adequacy than is Se content of tissue. The magnitude of GSH-Px activities observed in both ewes and their lambs therefore indicates that the Se administered by intramuscular injection was highly available. Se in the drench was also readily available but that in the ruminal pellets and the ESe salt was utilized less efficiently.

On the basis of these studies, the efficacy of the four treatments investigated may be ranked in decreasing order as follows: (I) intramuscular injection of Se and vitamin E, (2) oral drench of Se and vitamin E, (3) ESe salt, (4) ruminal Se pellet.

The author wishes to thank F. Hoffmann-La Roche \& Co., Basle, for the gift of Injacom E-SE. Permasel Se pellets were supplied through the courtesy of Tasman Vaccine Laboratory (Australia) Pty Ltd. Special thanks are due to Mr D. Solomon, Roche Products (Pty) Ltd, South Africa, for helpful assistance at all times and for organizing the transport of samples to Switzerland. The financial support of the University of Pretoria (NPK Fund) is gratefully acknowledged.

\section{REFERENCES}

Alderson, N. E., Mitchell, G. E., Little, C. O., Warner, R. L. \& Tucker, R. E. (1971). J. Nutr. 1or, 655.

Allaway, W. H. \& Hodgson, J. F. (1964). J. Anim. Sci. 23, 27 I.

Ammerman, C. B. \& Miller, S. M. (1975). J. Dairy Sci. 58, r 561 .

Andrews, E. D., Grant, A. B. \& Brunswick, L. F. C. (1974). N.Z. vet. J. 22, 46.

Andrews, E. D., Hogan, K. G. \& Sheppard, A. D. (1976). N.Z. vet. J. 24, I I I.

Association of Official Agricultural Chemists (1970). Official Methods of Analysis, I I th ed. Washington, DC: Association of Official Agricultural Chemists.

Boyd, J. W., Leyland, A. \& Baker, J. R. (1975). Vet. Rec. 98, 490.

Buchanan-Smith, J. G., Nelson, E. C., Osburn, B. I., Wells, M. E. \& Tillman, A. D. (1969). J. Anim. Sci. 29, 808.

Burton, V., Keeler, R. F., Swingle, K. F. \& Young, S. (1962). Am. J. vet. Res. 23, 96. 
Cousins, F. B. \& Cairney, I. M. (1961). Aust. J. agric. Res. 12, 927.

Culik, R., Bacigalupo, F. A., Thorp, F., Luecke, R. W. \& Nelson, R. H. (195I). J. Anim. Sci. 10, 1006.

Godwin, K. O., Fuss, C. N. \& Kuchel, R. E. (1975). Aust. J. biol. Sci. 28, 251.

Günzler, W. A., Kremers, H. \& Flohe, L. (1974). Z. Klin. Chem. Klin. Biochem. 12, 444.

Hashim, S. A. \& Schuttringer, G. R. (1966). Am. J. clin. Nutr. 19, I 37.

Hidiroglou, M., Jenkins, K. J. \& Corner, A. H. (1972). Can. J. Anim. Sci. 52, 511.

Hopkins, K. L., Pope, A. L., Baumann, C. A. \& Kowalczyk, T. (1966). Wld Rev. Anim. Prod. 2 , I0I.

Horton, G. J. M., Owen, N. C., Horak, I. G. \& Schröder, J. (1977). Jl S. Afr. vet. med. Ass, 48, 99.

International Union of Biochemistry (1965). Enzyme Nomenclature, p. 7. Amsterdam: Elsevier.

Karmen, A. (1955). J. clin. Invest. 34, I 31 .

Lee, H. J. \& Kuchel, R. E. (1969). In Research reports. Division of Nutritional Biochemistry, Adelaide, Australia: CSIRO.

Lindberg, P. \& Lannek, N. (1970). In Trace Element Metabolism in Animals [C. F. Mills, editor]. Edinburgh: Livingstone.

Oksanen, H. E. (1967). In Selenium in Biomedicine [O. H. Muth, editor]. Westport, Connecticut: Avi Publishing Co.

Oldfield, J. E., Schubert, J. R. \& Muth, O. H. (1963). J. agric. Fd Chem. II, 388.

Olson, O. E., Palmer, I. S. \& Cary, E. E. (1975). J. Ass. off. Analyt. Chem. 58, 117.

Paulson, G. D., Broderick, G. A., Baumann, C. A. \& Pope, A. L. (1968). J. Anim. Sci. 27, 195.

Perry, T. W., Beeson, W. M., Smith, W. H. \& Mohler, M. T. (1976). J. Anim. Sci. 42, 192.

Snedecor, G. W. \& Cochran, W. G. (1967). Statistical Methods, 6th ed. Ames, lowa: Iowa State University Press.

Tollersrud, S. \& Ribe, O. (1967). Acta. vet. scand. 8, I.

Tucker, E. M. (1974). Res. vet. Sci. 16, 19.

Weismann, U., Colombo, J. P., Adam, A. \& Richterich, R. (1966). Enzym. Biol. Clin. 7, 266.

Wroblewski, R. \& LaDue, J. S. (1955). Proc. Soc. exp. Biol. Med. 90, 210. 